Teologia i Moralność, volumen 12(2017), numer 2(22)

doi: 10.14746/tim.2017.22.2.14

\author{
ANDRZEJ BOHDANOWICZ \\ Uniwersytet im. Adama Mickiewicza w Poznaniu \\ Wydział Teologiczny
}

\title{
Śmierć jako przejście do trzeciej fazy życia czlowieka w myśli Gustava Theodora Fechnera
}

Doświadczenie umierania i śmierci, które towarzyszy człowiekowi od początku jego istnienia, nie powinno właściwie stanowić dla niego niczego niezwykłego. Umieranie należy do naszego ziemskiego życia jako jego ostatni akt, a śmierć jest faktem, do którego nie sposób się przyzwyczaić. Śmierć, a szczególnie perspektywa własnej nieuniknionej śmierci, każe pytać o sens życia, ale także rodzi pytanie o życie po śmierci ${ }^{1}$. Refleksja na temat śmierci widzianej z perspektywy nowego życia będzie miała charakter teologiczny, a więc przekraczający świat doświadczenia empirycznego, ale czy przez to mniej ważny? Już dla Arystotelesa, choć ideałem nauki była bezinteresowna kontemplacja rzeczywistości z jej niezmienną podstawową strukturą, najwyższą formę poznania stanowiła metafizyka. Nowożytność odrzuciła taką wizję nauki, a na jej miejsce zaproponowała zdobywanie wiedzy użytecznej dla człowieka. Za racjonalne zaczęto uznawać wyłącznie to, co poddaje się sprawdzeniu eksperymentalnemu. Dobrze ilustruje to metafora Franciszka Baco$\mathrm{na}^{2}$, że przyrodę należy wziąć na tortury, by wydobyć z niej wszelkie sekrety, jakie kryje w swoim wnętrzu ${ }^{3}$. Dziś wiele dziedzin nauk zajmujących się człowiekiem potrafi sformułować o nim twierdzenia w dużym stopniu trafne i rzetelne, ale z natury rzeczy ograniczone. „Wiara i teologia, jak pisał wybitny

${ }^{1}$ Por. M. Machinek, Śmierć $w$ dyspozycji czlowieka. Wybrane problemy etyczne u kresu ludzkiego życia, Olsztyn 2004, s. 9.

${ }^{2}$ Francis Bacon, XVI-wieczny filozof angielski, jeden z najwybitniejszych przedstawicieli odrodzenia i baroku, eseista, polityk oraz prawnik. Uchodzi za jednego z twórców nowożytnej metody naukowej opartej na eksperymencie i indukcji. Jest też uważany za jednego z twórców empiryzmu.

${ }^{3}$ Por. Od redakcji, W poszukiwaniu właściwej miary dla nauki, „Ethos” 44 (1998), s. 5. 
niemiecki teolog Karl Rahner, mówią o człowieku, że jest tajemnicą, partnerem dla Boga, niepojętej Tajemnicy i dlatego inne nauki nie mogą go w pełni wyrazić ani ogarnąć"

Odwołując się do myśli Gustava Theodora Fechnera, XIX-wiecznego filozofa i biologa, profesora uniwersytetu w Lipsku, twórcy tzw. psychofizyki, tj. nauki badającej stosunek między duszą i ciałem, chcemy przedstawić kilka myśli na temat śmierci widzianej jako przejście do trzeciej fazy życia ludzkiego $^{5}$, gdzie pierwsza faza to ciągły sen, druga to na przemian sen i jawa, a trzeci etap życia - to ciągła jawa i wieczne czuwanie ${ }^{6}$.

\section{Fazy życia czlowieka}

W pierwszej fazie człowiek żyje pod sercem matki: samotnie, w ciemnościach. Z zarodka (połączonych gamet) rozwija się ciało człowieka i wykształcają się narządy, „narzędzia” niezbędne do rozpoczęcia fazy drugiej. Dziecko na etapie życia w łonie matki jest jeszcze ślepe na światło, blask i piękno, a chwila narodzin, czyli opuszczenia dobrze znanego mu, zasadniczo bezpiecznego łona matki, musi mu się wydawać czymś okrutnym i bolesnym. Kto wie, czy chwila wyjścia na świat, odcięcia od pępowiny i definitywnego rozstania $\mathrm{z}$ dotychczasowym przyjaznym środowiskiem, do którego przecież już nigdy nie powróci, nie wydaje się mu zamachem na jego życie. Gdyby już wtedy mogło mówić, może powiedziałoby: „boję się, bo to zupełnie obcy, nieznany mi świat, to chyba koniec, to śmierć. Nie chcę wyjść [...]"7 . Narodziny człowieka to przebudzenie się do istnienia na czas o wiele dłuższy w świecie zewnętrznym, pełnym dźwięków i barw, o wiele ciekawszym niż wcześniejsza 9-miesięczna faza pobytu w ciele matki.

W drugiej fazie człowiek żyje w towarzystwie innych, ale indywidualnie, tj. obok innych i wśród innych; żyje już w świecie rozjarzonym słońcem, które ukazuje mu zjawiskowy świat, naświetla go, choć tylko zewnętrznie, powierzchownie. Przez analogię do pierwszej fazy życia możemy powiedzieć, że w fazie drugiej, na bazie zarodka, który przekształcił się w ludzkie ciało i ma odpowiednie narządy, rozwija się twórczy duch przygotowujący sobie narzędzia do fazy trzeciej: człowiek uczy się podziwiać, kochać, zachwycać się, uwielbiać, adorować. Na tym etapie liczą się przeżycia estetyczne. Zwróćmy

${ }^{4}$ K. Rahner, Człowiek, w: K. Rahner, H. Vorgrimler, Mały słownik teologiczny, Warszawa 1996.

${ }^{5}$ Por. A Marcol, Gustav Theodor Fechner-życie i twórczość, Nysa 2006 (mps).

${ }^{6}$ Por. Gustav Theodor Fechner, w: The 1911 Encyclopedia, https://www.york.ac.uk/depts/maths/histstat/fechner_biog.htm [dostęp: 07.10.2016].

${ }^{7}$ Por. H. Nouwen, Die Geburt, w: Lasst uns end-lich leben, Hg. A. Paessens-Deege, Berlin 2012, s. 159. 
uwagę, że są to akty duchowe. W tej fazie, w której wszyscy żyjący obecnie na Ziemi się znajdujemy, rozkwita boski zarodek ducha tkwiący w każdym człowieku. Wskazuje on na zakrytą jeszcze, tajemniczą rzeczywistość, którą poznamy dopiero $w$ trzeciej fazie, na świat przekraczający doczesność.

$\mathrm{Na}$ drugim etapie życia nasza świadomość i duch mają jeszcze oczy „na uwięzi”. Według Platona uwięziony w ciele duch natrafia ciągle na bariery i granice. Oprócz przeczuć i pragnień, jakie żywimy, niewiele jeszcze wiemy o prawdziwej wolności, blasku, olśnieniu i wspaniałościach życia na etapie końcowym. „Domyślamy” się go, przeczuwamy, a nawet wierzymy, że istnieje, bo upewnia nas o tym objawienie (por. Mt 22,32), wielcy myśliciele, a zwłaszcza święci.

Z pism rzymskiego poety Horacego ( $65 \mathrm{aX}-8 \mathrm{pX})$ pochodzi często powtarzane słowo nadziei: non omnis moriar ${ }^{8}$, choć w dalszej części tekstu poeta dodaje: „do nieba powrót odwlekaj”. Jan Paweł II, trawestując słowa Horacego, mówi: „To, co we mnie niezniszczalne, stanie twarzą w twarz z Tym, który jest”", a św. Teresa z Lisieux przed śmiercią oświadcza: „Nie umieram, lecz wchodzę do życia" "10. Nikaraguańczyk Ernesto Cardenal, nominowany do Nagrody Nobla w latach 2005 i 2007, pisze: ,Jesteśmy jak wędrowne ptaki, które lęgły się w odległych północnych krajach, ale odczuwają tajemniczy niepokój, tęsknotę za wiosenną ojczyzną, której dotychczas nie widziały" $\mathrm{W}$ innym miejscu przywoływany autor stwierdza:

Kłamstwem jest twierdzić, że życie jest krótkie. Nasze życie nie jest krótkie, lecz wieczne. Mamy przed sobą nie śmierć, lecz wieczność. [...] Nie narzekajmy na ulotność czasu, życie się nie kończy. Kończy się tylko czas, a potem nastaje wieczność, zawsze trwająca teraźniejszość. [...] Nie lękajmy się śmierci: nie znikamy, lecz przechodzimy w doskonałe, prawdziwe, żywsze życie - jak larwa (gąsienica), która w swoim kokonie zasypia, a potem budzi się przemieniona w pięknego motyla ${ }^{12}$.

Przejście z pierwszej fazy życia do drugiej nazywamy narodzinami, zaś przejście z drugiej do trzeciej zwyczajowo - umieraniem.

${ }^{8}$ Horacy, Pieśni, III, 30,6,https://pl.wikisource.org/wiki/Pie\%C5\%9B\%C5\%84_III,_30.

9 Jan Paweł II, Wspólnota osób jako obraz Boży, „Życie i Myśl” 8-9 (1980) s. 103.

${ }^{10}$ E. Pawłowska, Geniusz kobiety, 2009, s. 254 (mps).

${ }^{11}$ E. Cardenal, Wir sind wie Zugvoegel, w: Lasst uns end-lich leben, Hg. A. Paessens-Deege, Goch 2004, s. 50.

${ }^{12}$ Tamże, s. 137. 


\section{2. Śmierć jako brama do trzeciego etapu życia}

Zjawiska towarzyszące umieraniu człowieka intrygowały ludzkość od niepamiętnych czasów. Próbowano je sobie tłumaczyć, odwołując się do aktualnej wiedzy, uzupełniając luki wyobrażeniami spoza świata natury. Śmierć człowieka pozostawała jednak w jakimś stopniu tabu, a próby przeniknięcia jej istoty doprowadzały do tworzenia i utrwalania mitów oraz wyobrażeń o charakterze ponadnaturalnym. W połowie XVIII wieku w Europie doszło do gwałtownej zmiany w podejściu do śmierci - zaczęto ją traktować jako zjawisko biologiczne - putrefakcję (gnicie). Biologizacja śmierci spowodowała jej medykalizację, czyli „przejęcie” umierania i śmierci przez medycynę za wyraźnym przyzwoleniem społecznym. Kiedyś umieranie w domu, wśród rodziny było powszechnym rytuałem, obecnie ludzie umierają najczęściej w szpitalach lub hospicjach, a śmierć w domu należy do rzadkości. Kiedyś zwłokami zajmowała się rodzina, ona odpowiadała za umycie, ubranie, organizację pogrzebu, a zwłoki do dnia pochówku przebywały w domu. Teraz tymi wszystkimi czynnościami zajmują się wyspecjalizowane firmy, a kontakt rodziny z ciałem zmarłego jest maksymalnie ograniczony.

Odkrycia naukowe połowy XX wieku (głównie wprowadzenie respiratora) spowodowały, że walka ze śmiercią stała się coraz ważniejszym zadaniem medycyny. Nestor polskich medyków Kornel Gibiński mawiał ze smutkiem: „Lekarze leczą śmierć [...] zamarzyliśmy, by życie jak najdłużej utrzymać. Zaczęliśmy walczyć ze śmiercią"13. Jednak radykalny rozwój wiedzy biologicznej na temat śmierci człowieka nie podważył w sposób istotny fundamentalnych zasad filozofii i wiary w tym obszarze. Wręcz przeciwnie - przyniósł wiele wyjaśnień, ale także zrodził nowe pytania, angażując nie tylko autorytety medyczne, ale także środowiska filozofów i teologów. Nadal niekwestionowana pozostaje zasadnicza cecha śmierci - jej nieodwracalność. Mamy świadomość, że śmierć, która jest ostatecznym etapem umierania, ma charakter zdysocjowany (łac. dissociatio, = rozdzielenie) - jest rozłożona w czasie i wieloetapowa. Ta właśnie cecha - zdysocjowanie procesów śmierci - legła u podstaw egzystencjalnego pytania o granice ratowania ludzkiego życia, a co immanentnie z tym związane, o stwierdzenie momentu śmierci człowieka potencjalnego dawcy dla dynamicznie rozwijającej się transplantologii ${ }^{14}$.

Dzięki relacjom osób, które przeżyły śmierć kliniczną, umieranie wyobrażamy sobie jako przejście przez ciasny, ciemny tunel w kierunku światła, do s. 185.

${ }^{13}$ K. Szewczyk., Etyczna strona prób klinicznych fazy I w onkologii, „Diametros” 19 (2009),

${ }^{14}$ Por. P. Nowacki, Śmierć mózgu - ewolucja koncepcji z uwzględnieniem potrzeb transplantologii, w: Transplantologia. Oczekiwania. Możliwości. Granice, red. A. Dymer, Szczecin 2012, s. $39-40$. 
wieczności, z której nie ma powrotu. Jednak w integralnej wizji człowieka śmierć, której się często lękamy, to nic innego, jak właśnie drugie narodziny - tym razem do ostatecznego, pełnego życia. W starożytności chrześcijańskiej śmierć, szczególnie męczeńską, za wiarę, uznawano za dies natalis - dzień narodzin dla nieba. W takiej perspektywie, człowiek ze swego quasi-embrionalnego stanu ducha i etycznego rozwoju, ze swego minimum, z jakim przychodzi na świat, powinien w ciągu ziemskich dni dążyć do optimum, sięgać po to, co Gustav Fechner nazywa „narodzinami do wolności bytowania”, kiedy to „duch swoją ciasną powłokę rozsadza i porzuca tak, jak uczyniło dziecko ze swoją powłoką przy pierwszym narodzeniu" ${ }^{15}$. Jak błony płodowe, które w czasie embrionalnego rozwoju żywią i chronią dziecko, mają tylko przejściowe znaczenie, tak ciało ludzkie, które kryje w sobie „,brylant ducha w bezpiecznym futerale", ma też tylko przejściowe znaczenie. Wieczną, nieprzemijalną wartość ma tylko personalne jądro człowieka, mianowicie napełniony, ubogacony, ozłocony wartościami duch. Wraz ze śmiercią ciała nie przepadnie to, co człowiek, korzystając $\mathrm{z}$ danej mu już na Ziemi wolności, wypracował w czasie ziemskiego życia, kształtując i rozwijając zdolności duchowe, kontemplatywne, spekulatywne i afektywne. Są to obszary, które w wieczności jakby niematerialne zwierciadła (anteny) będą wychwytywać nieprzemijające światła i dźwięki ${ }^{16}$.

Należy pamiętać, że „Bóg nie jest Bogiem umarłych, ale żyjących” (Mk 12,27). To znaczy, nie pobudza do życia duchowego, nie każe mu rozkwitać i rozwijać się, aby je potem strącić w nicość. Potwierdzeniem tej prawdy objawionej może być pewna analogia pomiędzy pierwszą a drugą fazą życia. Mianowicie, każdy biolog, widząc rozwijające się oko czy ucho u płodu ludzkiego, wie, że są one przeznaczone do odbierania odpowiednio światła i dźwięków. Jest też świadomy, że istnieje rzeczywistość, która temu odpowiada, choć embrionalna istota ludzka tej rzeczywistości światła jeszcze nie ogląda ani nie słyszy jeszcze dźwięków. Natura non fallitur! ('Natura nas nie zawodzi!').

Miejmy jednak świadomość, że ziemskie oko i ucho kiedyś się zamkną... przy powtórnym narodzeniu. Wtedy oko i ucho ducha otworzą się na blask, światło, okazałość i przepych tamtego świata - na rzeczywistość uszczęśliwiającą - przy założeniu, że to wewnętrzne oko i ucho było na Boga nastrajane, tak jak ziemskie oko i ucho nastrojone jest na światło i dźwięk. Teologia nazywa to visio beatifica. „Ani oko nie widziało, ani ucho nie słyszało, co Bóg przygotował tym, którzy Go miłują" (1 Kor 2,9). Wynika z tego jasno, że ostatecznym i najwyższym zadaniem człowieka na Ziemi jest otwarcie, wyostrze-

\footnotetext{
${ }^{15}$ A. Marcol, Gustav Theodor Fechner-życie i twórczość, Nysa 2006 (mps), s. 6.

16 Por. tamże, s. 12.
} 
nie i poszerzenie zmysłów na świat przyszły - otwarcie wewnętrznego ucha, aby chwytało coraz delikatniejsze impulsy, sygnały i fale wieczności i słyszało ciche wezwanie Boże, wyrażające się głosem sumienia.

Inspirującym materiałem do refleksji w odniesieniu do śmierci i życia po śmierci są myśli znanego polskiego teologa ks. prof. Wacława Hryniewicza ${ }^{17}$. W jednym ze swoich ostatnich wywiadów udzielonym po przeżyciu śmierci klinicznej stwierdza on:

ze śmiercią wiąże się zwykle lęk pomieszany z ciekawością. Śmierć jest tajemnicą. Przybliżyłem się do niej niedawno. Przeszedłem operację nowotworu. Przeżyłem śmierć kliniczną. Temu przeżyciu towarzyszyło jednak odczucie spokoju. Nie odczuwam lęku przed „strasznym Sądem Bożym” - jak go określa tradycja chrześcijańskiego Wschodu. Wierzę, że Bóg rozumie nas lepiej niż my siebie. Że gotów jest nie tylko wybaczać, ale i zdumiewać. Zetknięcie z przyszłym światem jest sferą wielkiego zdumienia. Nie sięgają tam ludzkie wyobrażenia - stąd nasza ciekawość. Nie doświadczyłem tego, o czym mówią inni w licznych publikacjach. Nie przechodziłem przez tunel do światła. Raczej spokojnie zapadałem się w życzliwą ciemność. Ciemność ta była jednak - mówiąc paradoksalnie - w jakiś sposób świetlista. Z ufnością - trudno mi tu znaleźć odpowiednie słowo - opadałem, zstępowałem. Nie jest to spadanie gwałtowne, tylko raczej pogrążanie się w przyjaznej ciemności, która ma w sobie coś z rozjaśnienia. Nasz język nie rejestruje takich odcieni, dlatego musimy z konieczności uciekać się do paradoksów. Są w naszym życiu doświadczenia niepowtarzalne, takie, którymi nie sposób nawet dzielić się bez reszty z innymi. Zostało mi dane przeżycie, które uczyniło mnie spokojniejszym i więcej rozumiejącym ${ }^{18}$.

Są jednak ludzie, dla których śmierć nie jest spotkaniem z Bogiem, lecz raczej ostatecznym zamknięciem. Ksiądz prof. Hryniewicz podpowiada nam w tej kwestii taką intuicję.

Mam kontakty z ludźmi niewierzącymi. Znam różnego rodzaju odpowiedzi: śmierć to wieczny sen, definitywne rozpłynięcie się w nicość, wejście w sferę nieistnienia. Człowiek umiera i koniec. Po swojej śmierci klinicznej odczułem o wie-

${ }^{17}$ Ksiądz prof. Wacław Hryniewicz jest jednym z najwybitniejszych i najbardziej znanych w świecie polskich teologów. Założyciel i przez długi czas dyrektor Instytutu Ekumenicznego KUL, a także członek Międzynarodowej Komisji Mieszanej ds. Dialogu Teologicznego między Kościołem Rzymskokatolickim i Kościołem prawosławnym.

18 „Pogrążałem się w przyjaznej ciemności”. Ks. prof. Hryniewicz przeżył śmierć kliniczną. Czy boi się własnej śmierci?" , Ks. prof. Wacław Hryniewicz w rozmowie z Sebastianem Dudą, NEWSWEEK, 72.10.2016, s. 12, http://www.newsweek.pl/polska/-pograzalem-sie-w-przyjaznej-ciemno sci--ks--prof--hryniewicz-przezyl-smierc-kliniczna--czy-boi-sie-wlasnej-smierci,38371,1,1.html [dostęp: 27.10.2016]. 
le mocniej, jak wielkim darem jest istnienie. Jestem, a przecież mogłoby mnie w ogóle nie być. W swoim istnieniu otrzymałem coś jedynego i niepowtarzalnego. Często otrzymuję listy od ludzi wierzących, którzy także rozmawiają z niewierzącymi. W listach tych pojawia się zarzut, że wszystko, co robią teologowie, to tylko mniej lub bardziej udana spekulacja. No cóż, jako ludzie wierzący możemy jedynie dawać wyraz swojej wierze w wydarzenia ostateczne. Wiem, że same słowa nie trafiają do przekonania niewierzącym, którzy także w obliczu śmierci chcą konsekwentnie przyjąć los człowieka takim, jak go pojmowali w ciągu swego życia. Są wewnętrznie przeświadczeni, że po śmierci nie ma żadnej rzeczywistości, która miałaby nas czymś zaskakiwać. Nigdy nie usiłowałem takich ludzi przekonywać. Mówiłem: Jeśli tak chcesz i uważasz to za stuszne, idź swoją droga do końca, bo ostatecznej weryfikacji po tej stronie nie ma. Jako człowiek wierzący dzielić się mogę tylko swoim zaufaniem do obietnic, o których dowiaduję się z natchnionych ksiąg Biblii. Znam ewangelie, znam obietnice Jezusa. Wiem, że nawet ludzie wierzący często mają kłopoty z samą postacią Chrystusa. Wikłają się, pytają, kim On jest naprawdę - czy tylko człowiekiem, w którym Bóg rzeczywiście objawił swoją specjalną obecność, czy jedynie niezwykłym mędrcem, ale tylko człowiekiem. Rozumiem ludzi niewierzących, bo wiara nie jest łatwa. Chyba zbyt łatwo mówi się, że to łaska, która jednemu zostaje dana, a drugiemu nie. Jako ludzie myślący chcemy sami się przekonać i zrozumieć sens wiary. Być może jednak dopiero wtedy, gdy wierzymy, rozumiemy więcej. Może pewna sfera jest zamknięta dla tych, którzy takiego ostatecznego zaufania w sobie nie mają i nie odczuwają jego potrzeby ${ }^{19}$.

$\mathrm{Na}$ temat wieczności wypowiadali się także różni filozofowie. Na przykład, Leszek Kołakowski w wywiadzie rzece stwierdza:

Wolno nam wierzyć, że cały świat naszego doświadczenia nie jest realnością ostateczną. [...] Tak, ja w to wierzę. A nawet mam ochotę powiedzieć - ja to wiem. [...] Mam poczucie, że wiem, iż świat naszego doświadczenia jest przejawem świata Ducha. Jak się ma ten świat niewidoczny - albo prawie niewidoczny, bo bywa doświadczany tylko w niepewnych i bardzo rzadkich chwilach - do świata doświadczenia codziennego, nie potrafimy powiedzieć. Wszystkie religie tę właśnie intuicję fundamentalną obudowują wielością rozmaitych dogmatów i mitów [...]. Ale taka intuicja fundamentalna jest obecna”. „Wiara chętnie idzie w parze nie tylko z rozumem dyskursywnym, lecz także z rozumem intuicyjnym, który działa na skróty, wybiega naprzód, widząc wynik, cel czy kres w olśnieniu i wglądzie sięgającym w głąb tajemnicy istnienia. Jest coś zastanawiającego w tym, że istniejemy. Leibnizowskie pytanie: Dlaczego coś jest, a nie raczej nic ciągle pojawia się na horyzoncie naszego myślenia. Gdy wierzę, myślę jednocześnie, że

${ }^{19}$ Tamże, s. 15. 
w śmierci przechodzę w rzeczywistość nową, niepoznawalną i niedotykalną po tej stronie życia. Jako wierzący mogę się jednak tylko dzielić swoim doświadczeniem wiary i nadziei ${ }^{20}$.

$$
* * *
$$

Chrześcijaństwo wymaga zaufania Tajemnicy. Chrześcijanie nie wierzą w Boga samotnego, ale w Boga, który jest istotą komunijną, interpersonalną. Dialog toczyć się będzie przez wieki. Trzeba mieć odwagę przyjmowania życia jako daru - od losu, od natury czy, jeśli wierzysz, od Boga. Taką odwagą wykazują się zresztą również ludzie niewierzący, którzy otwierają się na innych, są życzliwi i szlachetni, zdolni do współczucia. Wspólnie z niewierzącymi jesteśmy uczestnikami wielkiej przygody życia. Wierzymy, że to życie przemienia się, że dokonują się w nim różne metamorfozy, że idziemy w kierunku nieznanego. I może dobrze, że to, co po śmierci - pozostaje dla nas nieznane. Inaczej zostalibyśmy z samą wiedzą, bez wiary i nadziei. A tak mamy obietnice, którym można w sposób racjonalny zaufać. Wiara jest w chrześcijaństwie przede wszystkim zawierzeniem - ufnością w spełnienie obietnic, złożonych przez samego Boga.

\section{DEATH AS A TRANSITION TO THE THIRD STAGE OF LIFE IN THE THOUGHT OF GUSTAV THEODOR FECHNER}

\section{Summary}

Although dying as the last act of life constitutes part of our earthly existence, death is difficult to accept. Faced with death an individual has always started asking questions about the meaningfulness of his/her life and life after death. In the contemporary western culture characterized among others by the collapse of the social structures, people very rarely die surrounded by their families as they used to do, but in hospitals, i.e. in isolation, suffering from loneliness, connected to a range of technologically advanced medical devices. Socio-cultural changes have brought about a conviction that death ends human existence. Catholic faith, however, offers hope that death provides access to desirable future events. As a pass-through state death is the end and the beginning, since after death life is transformed. Consequently, we die trustfully hoping to be rewarded with eternal life.

\footnotetext{
${ }^{20}$ L. Kołakowski, Czas ciekawy, czas niespokojny, cz. II, Kraków 2008, s. 184-185.
} 
Slowa kluczowe: narodziny; życie; umieranie; śmierć; życie po śmierci; nadzieja

Keywords: birth; life; dying; death; life after death; hope

\section{BIBLIOGRAFIA}

Cardenal E., Wir sind wie Zugvoegel, w: Lasst uns end-lich leben, Hg. A. Paessens-Deege, Santiago Verlag, Goch 2004.

Jan Paweł II, Wspólnota osób jako obraz Boży, „Życie i Myśl” 8-9 (1980), s. 103-114.

Kołakowski L., Czas ciekawy, czas niespokojny, cz. II, Kraków 2008, s. 184-185.

Machinek M., Śmierć w dyspozycji człowieka. Wybrane problemy etyczne u kresu ludzkiego życia, Olsztyn 2004.

Nouwen H., Die Geburt, w: Lasst uns end-lich leben, Hg. A. Paessens-Deege, Berlin 2012.

Nowacki P., Śmierć mózgu - ewolucja koncepcji z uwzględnieniem potrzeb transplantologii, w: Transplantologia. Oczekiwania. Możliwości. Granice, red. A. Dymer, Szczecin 2012, s. 39-40.

Rahner K., Człowiek, w: Rahner K., Vorgrimler H., Mały słownik teologiczny, Warszawa 1996.

Szewczyk K., Etyczna strona prób klinicznych fazy I w onkologii, „Diametros” 19 (2009), s. 185$-203$.

ANDRzeJ BohDanowicz (1960), ks. prof. UAM dr hab., teolog moralista, specjalizuje się w zagadnieniach teologii małżeństwa i rodziny, etyce seksualnej oraz bioetyce. 